\title{
Effects of lactic acid bacteria inoculant on quality, fermentation profile and nutritive value of alfalfa silage at different ensiling period
}

\author{
Bunyamin AKTÜRK ${ }^{\mathrm{a}}$, Hıdır GÜMÜŞs, \\ Burdur Mehmet Akif Ersoy University, Faculty of Veterinary Medicine, Department of Animal Nutrition and Nutritional Disease, \\ Burdur, TURKEY \\ aORCID: 0000-0003-4325-8311; ' ORCID: 0000-0001-7077-1036 \\ ${ }^{\bowtie}$ Corresponding author: hgumus@ mehmetakif.edu.tr \\ Received date: 24.09.2019- Accepted date: 21.01.2020
}

\begin{abstract}
The present study was carried out to investigate the effects of lactic acid bacteria inoculant on quality, fermentation profile and nutritive value of alfalfa silage at different fermentation periods. After harvesting, fresh alfalfa samples were packed into polyethylene film and the commercial lactic acid bacteria inoculant was used as silage additive. Totally of 21 silage packages were opened by weekly for the analysis. Smell, color, structure, and total scores of alflalfa silage were significantly increased from the first week. Silage quality was determined medium at $7^{\text {th }}$ day; good between $14^{\text {th }}$ and $42^{\text {th }}$ days; excellent at $49^{\text {th }}$ day. The Flieg point was gradually increased after $\mathrm{d} 28$ of ensiling $(\mathrm{P}<0.05)$. While $\mathrm{pH}$ was reduced at 5.15 ; NH3-N/TN content of alfalfa silage was increased at $15.70 \%$ at the end of the study. We observed an increase in acetate concentration and decrease in propionate and butyrate concentrations in the alfalfa silage. Lactate concentration was significantly increased on day 35 of the fermentation $(\mathrm{P}<0.05)$. Crude fiber (CF), crude protein (CP), ether extract (EE), neutral detergent fiber (NDF), acid detergent fiber (ADF) contents of alfalfa silage were decreased, whereas nitrojen free extract (NFE) and non-fiber carbohydrate (NFC) were increased during ensiling period. According to our findings, fermentation period had a significant effect on digestible dry matter, dry matter intake and relative feed value of alfafa silage $(\mathrm{P}<0.05)$.
\end{abstract}

Keywords: Alfalfa silage, chemical composition, fermentation parameters, silage quality.

\section{Laktik asit bakteri inokulantının farklı silolama dönemlerindeki yonca silajının kalitesi, fermentasyon profili ve besin madde değeri üzerine etkisi}

Özet: Bu çalışma laktik asit bakteri inokulantının farklı silolama dönemlerindeki yonca silajının kalitesi, fermentasyon profili ve besin madde değerleri üzerine olan etkilerini incelemek üzere yapılmıştır. Taze yonca örnekleri hasat edildikten sonra polietilen film ile paketlenmiş ve silaj katkısı olarak ticari laktik asit bakteri inokulantı kullanılmıştır. Haftalık olarak toplam 21 adet silaj paketi analizler için açılmıştır. Birinci haftadan itibaren yonca silajının koku, renk, strüktür ve toplam puanları önemli düzeyde artış göstermiştir. Silaj kalitesinin; 7. günde 'orta'; 14 ile 42. günler arasında 'iyi'; 49. günde 'pekiyi' nitelikli olduğu tespit edilmiştir. Silolamanın 28. gününden itibaren Flieg puanı önemli derecede $(\mathrm{P}<0,05)$ artış göstermiştir. Çalışmanın sonunda yonca silajının $\mathrm{pH}$ değeri 5.15'e kadar azalmış; amonyok azotu içeriği \%15,70' e kadar yükselmiştir. Yonca silajınında asetat konsantrasyonunun arttığı, propiyonat ve bütirat konsantrasyonunun azaldığ gözlenmiştir. Laktat konsantrasyonu, fermentasyonun 35. gününde önemli derecede $(\mathrm{P}<0,05)$ artmıștır. Silolama boyunca, yonca silajının azotsuz öz madde ve lif olmayan karbonhidrat kısmı artarken, ham sülüloz (HS), ham protein (HP), ham yağ (HY), nötral deterjan lif (NDF), asit deterjan lif (ADF) içerikleri azalmıştır. Farklı fermentasyon zamanlarının sindirilebilir kuru madde (SKM), kuru madde tüketimi (KMT) ve nispi yem değeri (NYD) üzerine etkileri önemli $(\mathrm{P}<0,05)$ bulunmuştur.

Anahtar sözcükler: Fermentasyon parametleri, kimyasal kompozisyon, silaj kalitesi, yonca silaj1.

\section{Introduction}

Although grazing is the most common and economical way to feed cattle, climatic and geographical conditions may not allow grazing for a year. For livestocks the availability of the pastures depends on seasons and the factors that affects the growth of the plants (E.g.; temperature, light, quantity of rain) are different for every season (11). Production of the high-quality roughage is difficult because of the ecological reasons in some seasons. Therefore, the animals could not consume high- 
quality roughage in several seasons, which results in decreased animal performance (1). Alfalfa is important for the animal nutrition due to its high protein content (36) and it is used in various forms, such as silage, hay and dehydrated plants (29). In modern farming, cattle and sheep are fed with alfalfa ration for source of protein instead of maize silage (12). In this context, silage making is an important method to substitute high-quality roughage (6). The preservation of roughage as silage is depend on to anaerobic environment and $\mathrm{pH}$ decreases because of the lactic acid fermantation and occuring high osmotic pressure provides inactivation of the microorganisms (24). Type of the fermantation in silage depends on the environmental conditions, types of microorganism and substrate availabilty (26). During fermentation, watersoluble carbohydrate (WSC) is converted into lactic acid (LA) via epiphytic lactic acid bacteria (LAB) resulting in decline of $\mathrm{pH}$ (21). LAB are commonly used as silage additive which reported to decrease ammonia nitrogen/total nitrogen $\left(\mathrm{NH}_{3}-\mathrm{N} / \mathrm{TN}\right)$ (20) and $\mathrm{pH}$ level while increasing lactic acid concentration and number of LAB in silage (30). Homofermantative $\left(\mathrm{Homo}^{\mathrm{LAB}}\right)$ and heterofermantative (Hete ${ }^{\mathrm{LAB}}$ ) types of lactic acid bacteria convert the hexose to the lactic acid with different pathways. Obligate homofermentative LAB (facultative heterofermentative LAB) convert hexose mainly into lactic acid via Embden-Meyerhof-Parnas pathway whereas obligate heterofermentative LAB can ferment pentose besides hexose to produce acetate, ethanol, and $\mathrm{CO}_{2}$ as well as lactate (23). However, the most effective way in saving the energy is just lactic acid (>85\%) producing necessary Homo ${ }^{\mathrm{LAB}}$ (23). Heterofermantative lactic acid bacteria produced $\mathrm{CO}_{2}$ during the hexose fermantation which causes dry matter loss of silage. Although heterolactic acid bacteria can lead to large losses in dry matter, they enhance the aerobic stability in a variety of silages via the anaerobic degradation of lactic acid to acetic acid. (18).

Within this context, the principles of ensilage should be recognized to produce high quality silage (19). To ensile of alfalfa silage is difficult due to the its high protein content, high buffering capacity, low WSC and low dry matter (41). Possibility, LAB improve silage fermentation quality of alfalfa silage by decreasing the warming in silage and dry matter loss (41). When they added to the product, they have to accelerate the process of fermentation (19). Therefore, animals consuming highquality silages gain better performance and provide an economic advantage. (22). They might help to limit the undesirable secondary fermentation and increase feed value of the silage by preventing dry matter losses (43). Bacterial inoculants leave no residues and did not adversely affect animal health and safety (28). It has been recommended that the supplementation of LAB at more than $10^{5} \mathrm{CFU} \mathrm{g}^{1}$ when making silage in order to prevent clostirdial fermentation and effectively decrease the DM (36). Based on the previous study results, the current study investigated the effects of lactic acid bacteria inoculant on quality, fermentation profile and nutritive value of alfalfa silage at different ensiling period.

\section{Material and Methods}

Study design and silage preparation: The study was conducted at the Department of Animal Nutrition and Nutritional Diseases, Faculty of Veterinary Medicine, Burdur Mehmet Akif Ersoy University, located at 36 53' North latitude and $30^{\circ} 53^{\prime}$ East longitude and $950 \mathrm{~m}$ above sea level. Burdur is the transition region in the inner part of the western Mediterranean.

Alfalfa were sown as $6 \mathrm{~kg} / \mathrm{da}$ with seeder harvester. It was watered with 30 horsepower submerged pump after every mowing and $20 \mathrm{~kg} / \mathrm{da}$ ammonium nitrate (26\%) applied after each harvest. The fourth cuttings of fresh alfalfa (FA) was harvested by tractor 65 days after sowing at about $10 \%$ blooming phase for making silage in July 2018. When making silage, commercial lactic acid bacteria inoculant (Pioneer 11A44. Pioneer Hi-Bred International, Inc., Des Moines, IA, US) was used as silage additive. A day later, approximately $750 \mathrm{~kg}$ prepared fresh alfalfa wrapped up polyethylene silage film and packages were storaged indoor areas. After alfalfa silage was packed, 21 silage packages were opened by weekly from 3 different silage package during 7 weeks for the analysis of physical quality and fermentation profile (chemical composition, Flieg point, $\mathrm{pH}$ level, $\mathrm{NH}_{3}-\mathrm{N} / \mathrm{TN}$, lactic acid, and volatile fatty acid content of alfalfa silage on 7. 14.21. 28. 35. 42. and 49 days of ensiling.

Physical quality analysis: Physical quality analysis was assessed by using DLG scoring system (9). Each alfalfa silage samples were carefully opened and scored by 3 experts in terms of colour point (0-2), structure point (04 ), and scent point (0-14) of the silage. According to score; silage was divided into the quality classes Excellent (1620 points); Good (10-15); Mid (5-9) and too bad (0-4).

Fleig point (10) was calculated by using $\mathrm{pH}$ and $\mathrm{DM}$ values of alfalfa silage at different days of ensiling with the following equation:

Flieg's point $=220+(2 \times D M-15)-(40 \times p H)$

Fermentation profile analysis: For the assessment of $\mathrm{NH}_{3}-\mathrm{N} / \mathrm{TN}$ and $\mathrm{pH}, 25 \mathrm{~g}$ fresh alfalfa silage sample was blended with $100 \mathrm{ml}$ distilled water in a blender for 4-5 minutes and filtered through cheesecloth. The $\mathrm{pH}$ value of fresh alfalfa silage was determined with glass electrode $\mathrm{pH}$ meter (ECPlaza ${ }^{\circledR}$, Ecomet P25. Guro-gu, Seoul, Korea) from filtrate. $\mathrm{NH}_{3}-\mathrm{N} / \mathrm{TN}$ content of fresh alfalfa silage analysis were measured according to the Kjeldahl method (4). Approximately $10 \mathrm{ml}$ of filtrate was distilled (Vapodest 10 Rapid Kjeldahl Distillation Unit; Gerhardt, 
Konigswinter, Germany) and titrated to determine $\mathrm{NH}_{3}$ N/TN.

Volatile fatty acid concentration (31) of the alfalfa silage (acetate, propionate, butyrate) was measured using gas chromatography (GC; Agilent ${ }^{\circledR} 7890$ column; HPFFAP $30 \mathrm{~m} \times 0.53 \mathrm{~mm} \times 0.50 \mu \mathrm{m})$. Lactate of alfalfa silage was analyzed using the high-performance liquid chromatography (HPLC; Agilent Technologies, Inc., Berlin, Germany; column: interstil ODS-4. Sepax Technologies, Inc., Santa Clara, CA, USA; UV-VIS detector) described by (24). Opened silage samples were dried in a forced ventilation oven at $60{ }^{\circ} \mathrm{C}$ (Memmert $\mathrm{GmbH}{ }^{\circledR}$ Universal, Schwabach, Germany) for $48 \mathrm{~h}$ and milled at 1-mm sieve for the estimation of nutritional composition of silage. The DM (method 934.01), CP (method 984.13), ether extract (method 920.39. EE), and ash (method 942.05) contents were estimated according to the methods outlined by Association of Official Analytical Chemists (2). Crude fiber (CF) content was determined by the method previously described by Crampton and Maynard (7), whereas neutral detergent fiber (NDF) and acid detergent fiber (ADF) contents were determined according to Goering and Van Soest (15). Digestible dry matter (DDM) was determined by using ADF content of alfalfa silage $[D D M \%=88.9-(0.779 \times A D F \%)]$. Then dry matter intake (DMI) was measured by using NDF content of alfalfa silage $[D M I \%=120 / N D F \%)]$. Relative feed value was calculated (29) by using DDM and DMI $[R F V=D D M \% \times D M I \% \times 0.775]$. NFC (Non-Fibrous carbohydrates) was calculated (32) by using formula [100 - $(\% N D F+\% H P+\% H Y+\% H K)]$. NFE (Nitrogen Free Extract) was calculated (32) by using formula [\% KM $(\% H Y+\% H P+\% H K+\% H S)]$.

Statistical analyses: The statistical analysis was performed with SPSS program (Statistical Package for the Social Sciences; Inc., Chicago, IL, USA). Data were analysed by analysis of variance (ANOVA, General Linear Models) to determine the effects of lactic acid bacteria inoculant on silage quality, fermentation profile and nutritive value of alfalfa silage at different ensiling period. Differences among the groups were calculated using Duncan test (8). Level of significance was taken as $\mathrm{P}<0.05$.

\section{Results}

The physically quality (color, smell, structure and total score) of the alfalfa silage samples were significantly influenced $(\mathrm{P}<0.05)$ by weekly progression (Table 1$)$. In all parameters (color, smell, structure and total score) were significanlty increased from first week. The quality of alfalfa silage was determined on $7^{\text {th }}$ day as 'mid' on $14^{\text {th }}$ and $42^{\text {th }}$ days as 'good' and on day 49 as 'excellent'. The effects of different feed additives on $\mathrm{pH}$, Flieg point and $\mathrm{NH}_{3}-\mathrm{N} / \mathrm{TN}$ were shown in Table 1 . The Flieg point was the lowest at $\mathrm{d} 7$ of ensiling. After ensiling for 21 days a remarkable increase was observed in the Flieg point of alfalfa silages $(\mathrm{P}<0.05)$, due to the increased $\mathrm{DM}$ and decreased $\mathrm{pH}$. The $\mathrm{pH}$ value was linearly decreased and $\mathrm{NH}_{3}-\mathrm{N} / \mathrm{TN}$ content was increased during the weeks $(\mathrm{P}<0.05)$. The lowest $\mathrm{pH}$ value was recorded at $\mathrm{d} 49$ of ensiling with the value of 5.15. The highest $\mathrm{NH}_{3}-\mathrm{N} / \mathrm{TN}$ content was determined at d 49 of ensiling (15.70\%), while the lowest $\mathrm{NH}_{3}-\mathrm{N} / \mathrm{TN}$ content at $\mathrm{d} 7$ of ensiling in LAB $(9.60 \%)$. As shown in Table 3, alfalfa silage had the highest lactate and acetate concentration and the lowest propionate and butyrate at d 49 of ensiling. Acetate and propionate, as well as the butyrate concentration were $8.90,0.33$ and $0.49(\mathrm{~g} / \mathrm{kg}, \mathrm{DM})$, respectively. Lactate concentration was dramatically increased by 18 -fold at $\mathrm{d}$ 49 of ensiling as compared to at $\mathrm{d} 7$ of ensiling $(\mathrm{P}<0.05)$. Organic matter of the silage samples was increased throughout the ensiling period the first $7 \mathrm{~d}$ and kept increasing until d 49. CF, CP, EE, NDF, ADF contents of alfalfa silage were decreased, whereas NFE and NFC contents were increased during the weeks (Table 2). The CF contents of alflalfa silage on $\mathrm{d} 7$ and 49 of ensiling were $32.80 \%$ and $25.83 \%$, respectively, and its CP content were $16.86 \%$ and $14.30 \%$ on a DM, respectively. As shown in Figure 1, DDM and DMI was increased due to

Table 1. Physical quality and fermentation profile of alfalfa silage

\begin{tabular}{ccccccccc}
\hline Day & Smell & Color & Structure & Totally & Quality & Flieg point & pH value & NH3-N/TN $(\%)$ \\
\hline $7^{\text {th }}$ & $7.07 \pm 0.54^{\mathrm{a}}$ & $0.20 \pm 0.44^{\mathrm{a}}$ & $1.27 \pm 0.28^{\mathrm{a}}$ & $8.53 \pm 1.10^{\mathrm{a}}$ & Medium & $19.31 \pm 3.4^{\mathrm{a}}$ & $6.09 \pm 0.08^{\mathrm{a}}$ & $9.66 \pm 0.97^{\mathrm{a}}$ \\
$14^{\text {th }}$ & $8.47 \pm 0.55^{\mathrm{ab}}$ & $0.73 \pm 0.36^{\mathrm{ab}}$ & $2.67 \pm 0.33^{\mathrm{b}}$ & $11.87 \pm 0.56^{\mathrm{b}}$ & Good & $25.54 \pm 7.60^{\mathrm{a}}$ & $5.94 \pm 0.21^{\mathrm{a}}$ & $11.82 \pm .18^{\mathrm{b}}$ \\
$21^{\text {th }}$ & $8.93 \pm 0.92^{\mathrm{bc}}$ & $0.93 \pm 0.15^{\mathrm{b}}$ & $2.60 \pm 0.43^{\mathrm{bc}}$ & $12.47 \pm 1.37^{\mathrm{bc}}$ & Good & $27.05 \pm 5.33^{\mathrm{a}}$ & $5.95 \pm 0.10^{\mathrm{a}}$ & $11.92 \pm .45^{\mathrm{b}}$ \\
$28^{\text {th }}$ & $9.27 \pm 0.86^{\mathrm{bc}}$ & $0.87 \pm 0.51^{\mathrm{b}}$ & $2.93 \pm 0.15^{\mathrm{bc}}$ & $13.07 \pm 1.26^{\mathrm{bc}}$ & Good & $40.41 \pm 6.18^{\mathrm{b}}$ & $5.71 \pm 0.15^{\mathrm{b}}$ & $12.78 \pm 0.34^{\mathrm{bc}}$ \\
$35^{\text {th }}$ & $10.27 \pm 0.72^{\mathrm{cd}}$ & $1.07 \pm 0.14^{\mathrm{b}}$ & $2.93 \pm 0.49^{\mathrm{bc}}$ & $14.27 \pm 1.21^{\mathrm{cd}}$ & Good & $45.51 \pm 5.69^{\mathrm{b}}$ & $5.60 \pm 0.13^{\mathrm{b}}$ & $12.94 \pm 0.62^{\mathrm{bc}}$ \\
$42^{\text {th }}$ & $10.40 \pm 0.27^{\mathrm{cd}}$ & $1.87 \pm 0.29^{\mathrm{c}}$ & $3.33 \pm 0.47^{\mathrm{cd}}$ & $15.60 \pm 0.86^{\mathrm{cd}}$ & Good & $47.75 \pm 5.64^{\mathrm{b}}$ & $5.57 \pm 0.12^{\mathrm{b}}$ & $14.24 \pm 0.79^{\mathrm{cd}}$ \\
$49^{\text {th }}$ & $11.80 \pm 1.21^{\mathrm{d}}$ & $2.00 \pm 0.01^{\mathrm{c}}$ & $4.00 \pm 0.01^{\mathrm{cd}}$ & $17.80 \pm 1.22^{\mathrm{d}}$ & Excellent & $65.54 \pm 8.98^{\mathrm{c}}$ & $5.15 \pm .023^{\mathrm{c}}$ & $15.70 \pm 1.03^{\mathrm{d}}$ \\
$\mathrm{P}$ & $* *$ & $*_{*}^{*}$ & $* *$ & $* *$ & & $* *$ & $* *$ & $* *$
\end{tabular}

a-d;Values with different small letters show significant differences among ensiling days

* $\mathrm{P}<0.05$; ** $\mathrm{P}<0.01$; NS, not significant

$\mathrm{NH}_{3}-\mathrm{N} / \mathrm{TN}$ : Ammonia nitrogen/Total nitrogen 
Tablo 2. Nutritive value of alfalfa silage (DM\%)

\begin{tabular}{llllllllllll}
\hline Day DM & Ash & OM & CF & CP & EE & NDF & ADF & HES & NFE & NFC \\
\hline Day & $92.41 \pm 0.97^{\mathrm{a}}$ & $12.82 \pm 0.59^{\mathrm{b}}$ & $79.58 \pm 2.02^{\mathrm{a}}$ & $32.80 \pm 0.42^{\mathrm{a}}$ & $16.86 \pm 0.43^{\mathrm{a}}$ & $1.78 \pm 0.04$ & $43.36 \pm 0.99^{\mathrm{c}}$ & $33.61 \pm 0.90^{\mathrm{a}}$ & $9.75 \pm 0.25^{\mathrm{b}}$ & $35.87 \pm 0.68^{\mathrm{a}}$ & $25.15 \pm 0.86^{\mathrm{a}}$ \\
$7^{\text {th }}$ & $93.69 \pm 0.41^{\mathrm{ab}}$ & $12.95 \pm 0.01^{\mathrm{b}}$ & $80.74 \pm 0.32^{\mathrm{a}}$ & $32.24 \pm 0.76^{\mathrm{a}}$ & $15.96 \pm 0.41^{\mathrm{b}}$ & $1.71 \pm 0.16$ & $42.02 \pm 0.20^{\mathrm{c}}$ & $33.22 \pm 0.88^{\mathrm{a}}$ & $8.80 \pm 0.77^{\mathrm{ab}}$ & $37.28 \pm 0.84^{\mathrm{ab}}$ & $26.80 \pm 0.99^{\mathrm{ab}}$ \\
$14^{\text {th }}$ & $95.59 \pm 0.23^{\mathrm{bc}}$ & $13.55 \pm .61^{\mathrm{c}}$ & $82.03 \pm 0.63^{\mathrm{b}}$ & $31.84 \pm 0.37^{\mathrm{b}}$ & $15.74 \pm 0.37^{\mathrm{bc}}$ & $1.71 \pm 0.05$ & $41.21 \pm 0.31^{\mathrm{bc}}$ & $30.58 \pm 0.58^{\mathrm{b}}$ & $10.60 \pm 0.46^{\mathrm{b}}$ & $37.29 \pm 0.77^{\mathrm{b}}$ & $28.01 \pm 0.51^{\mathrm{b}}$ \\
$21^{\text {th }}$ & $95.15 \pm 0.45^{\mathrm{c}}$ & $12.67 \pm 0.69^{\mathrm{ab}}$ & $82.48 \pm 0.63^{\mathrm{b}}$ & $29.69 \pm 0.33^{\mathrm{c}}$ & $15.53 \pm 0.33^{\mathrm{bc}}$ & $1.60 \pm 0.12$ & $40.18 \pm 0.69^{\mathrm{b}}$ & $30.93 \pm 1.78^{\mathrm{b}}$ & $9.25 \pm 0.56^{\mathrm{ab}}$ & $40.81 \pm 0.54^{\mathrm{c}}$ & $30.26 \pm 0.78^{\mathrm{c}}$ \\
$28^{\text {th }}$ & $95.91 \pm 0.43^{\mathrm{c}}$ & $13.90 \pm 0.25^{\mathrm{c}}$ & $82.00 \pm 0.39^{\mathrm{b}}$ & $27.65 \pm 0.46^{\mathrm{d}}$ & $15.46 \pm 0.31^{\mathrm{bc}}$ & $1.61 \pm 0.18$ & $39.05 \pm 0.43^{\mathrm{b}}$ & $30.17 \pm 0.41^{\mathrm{b}}$ & $8.84 \pm 0.30^{\mathrm{ab}}$ & $41.45 \pm 0.68^{\mathrm{c}}$ & $29.94 \pm 0.55^{\mathrm{c}}$ \\
$35^{\text {th }}$ & $95.49 \pm 0.42^{\mathrm{c}}$ & $12.37 \pm 0.43^{\mathrm{ab}}$ & $83.12 \pm 0.48^{\mathrm{c}}$ & $28.76 \pm 0.47^{\mathrm{e}}$ & $15.08 \pm 0.54^{\mathrm{c}}$ & $1.56 \pm 0.14$ & $37.32 \pm 0.81^{\mathrm{a}}$ & $28.67 \pm 0.99^{\mathrm{c}}$ & $8.60 \pm 0.78^{\mathrm{ab}}$ & $41.98 \pm 0.33^{\mathrm{c}}$ & $33.53 \pm 0.99^{\mathrm{d}}$ \\
$42^{\text {th }}$ & $96.46 \pm 0.32^{\mathrm{c}}$ & $12.12 \pm 0.11^{\mathrm{a}}$ & $84.33 \pm 0.26^{\mathrm{c}}$ & $25.83 \pm 0.30^{\mathrm{f}}$ & $14.30 \pm 0.22^{\mathrm{d}}$ & $1.68 \pm 0.17$ & $36.70 \pm 0.81^{\mathrm{a}}$ & $29.68 \pm 0.70^{\mathrm{bc}}$ & $7.02 \pm 0.66^{\mathrm{a}}$ & $46.14 \pm 0.35^{\mathrm{d}}$ & $35.21 \pm 0.78^{\mathrm{d}}$ \\
$\mathrm{P}$ & $* *$ & $*$ & $* *$ & $*^{*}$ & $* * *$ & NS & $* *$ & $* *$ & $*$ & $* *$ & $* *$ \\
\hline
\end{tabular}

$* \mathrm{P}<0.05 ; * * \mathrm{P}<0.01 ; \mathrm{NS}$, not significant

a-d;Values with different small letters show significant differences among ensiling days

DM: Dry matter; OM: Organic matter; CF: Crude fiber; CP: Crude protein; EE: Ether extract; NDF: Nötral detergan fiber; ADF: Acit detergan fiber; HES: Hemicellulose; NFE: Nitrogen free extract; NFC: Non fiber carbonhydrate

$* \%$ NFE (Nitrogen Free Extract) $=\% \mathrm{KM}-(\% \mathrm{HY}+\% \mathrm{HP}+\% \mathrm{HK}+\% \mathrm{HS}) * \%$ NFC (Non-Fibrous carbohydrates) $=100-$ $(\% \mathrm{NDF}+\% \mathrm{HP}+\% \mathrm{HY}+\% \mathrm{HK})$

Tablo 3. Acetate, propionate, and lactate levels of alfalfa silage $(\mathrm{g} / \mathrm{kg}, \mathrm{DM})$

\begin{tabular}{ccccc}
\hline \multicolumn{1}{c}{ Day } & Acetate & Propionate & Butyrate & Lactate \\
\hline $7^{\text {th }}$ & $2.75 \pm 0.05^{\mathrm{a}}$ & $1.54 \pm 0.03^{\mathrm{a}}$ & $1.06 \pm 0.07^{\mathrm{a}}$ & $2.31 \pm 0.04^{\mathrm{a}}$ \\
$14^{\text {th }}$ & $2.57 \pm 0.06^{\mathrm{ab}}$ & $1.05 \pm 0.02^{\mathrm{b}}$ & $1.02 \pm 0.08^{\mathrm{a}}$ & $3.16 \pm 0.07^{\mathrm{a}}$ \\
$21^{\mathrm{th}}$ & $2.92 \pm 0.15^{\mathrm{bc}}$ & $0.71 \pm 0.04^{\mathrm{c}}$ & $0.78 \pm 0.14^{\mathrm{b}}$ & $3.07 \pm 0.16^{\mathrm{a}}$ \\
$28^{\mathrm{th}}$ & $3.08 \pm 0.04^{\mathrm{bc}}$ & $0.62 \pm 0.07^{\mathrm{d}}$ & $0.88 \pm 0.02^{\mathrm{b}}$ & $2.99 \pm 0.04^{\mathrm{a}}$ \\
$35^{\text {th }}$ & $3.34 \pm 0.07^{\mathrm{c}}$ & $0.45 \pm 0.01^{\mathrm{e}}$ & $0.87 \pm 0.02^{\mathrm{b}}$ & $23.60 \pm 0.51^{\mathrm{b}}$ \\
$42^{\text {th }}$ & $4.78 \pm 0.06^{\mathrm{d}}$ & $0.36 \pm 0.04^{\mathrm{f}}$ & $0.69 \pm 0.01^{\mathrm{c}}$ & $31.80 \pm 0.46^{\mathrm{c}}$ \\
$49^{\mathrm{th}}$ & $8.90 \pm 0.37^{\mathrm{e}}$ & $0.33 \pm 0.01^{\mathrm{f}}$ & $0.49 \pm 0.01^{\mathrm{d}}$ & $36.40 \pm 1.54^{\mathrm{d}}$ \\
$\mathrm{P}$ & $* *$ & $* *$ & $*$ & $* *$ \\
\hline
\end{tabular}

a-f; Values with different small letters show significant differences among ensiling days

$* \mathrm{P}<0.05 ; * * \mathrm{P}<0.01$

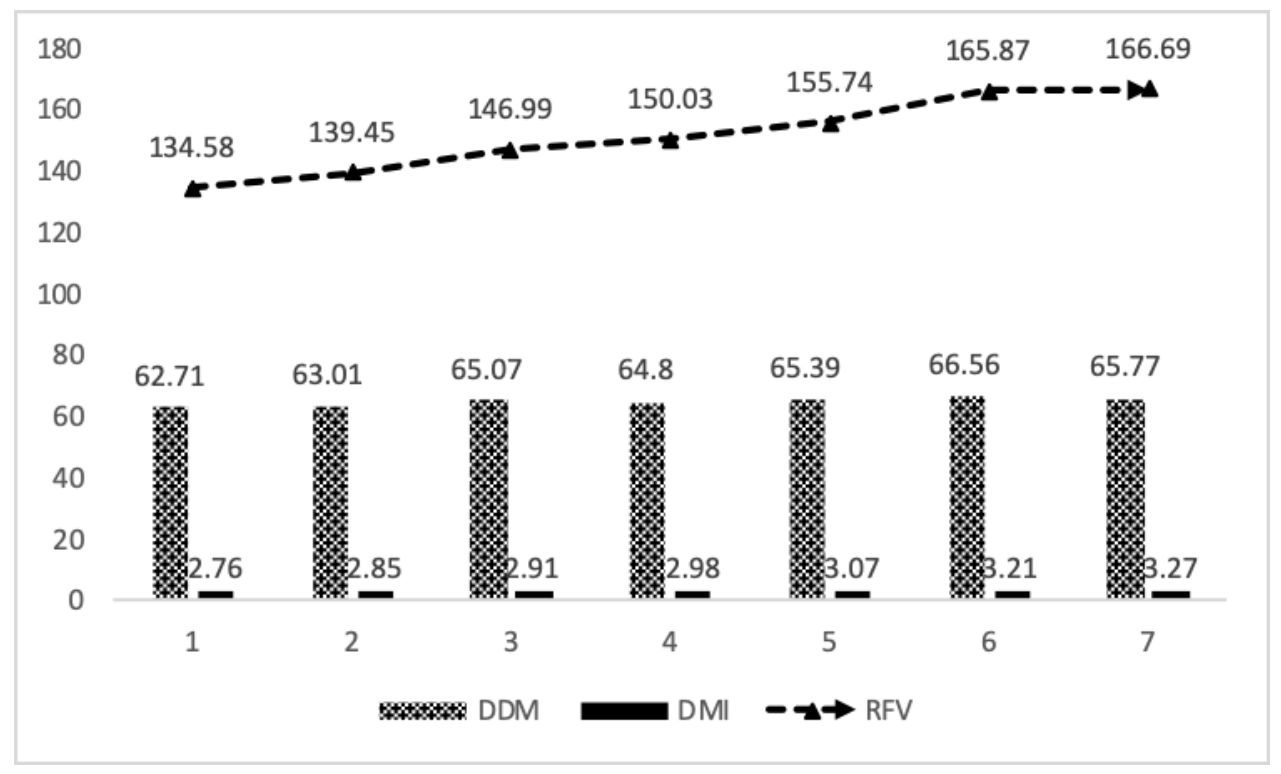

Figure 1. DDM, DMI and RFV levels of alfalfa silage (\%) DDM: Dry digestible matter; DMI: Dry matter intake; RFV: Relative feed value the decreasing ADF and NDF content of alfafa silage. The DDM and DMI of alfalfa silage were $65.77 \%$ and $3.27 \%$, respectively, and its $\mathrm{ADF}$ and NDF content were $36.70 \%$ and $29.68 \%$ at $d 49$ of ensiling, respectively $(\mathrm{P}<0.05)$.
RFV was positively improved due to the increasing DDM and DMI. The RFV was lower at $\mathrm{d} 7$ of ensiling by an average of $134.58 \%$ compared to end of ensiling (166.69\%). 


\section{Discussion and Conclusion}

Silage making is an important procedure of animal feed and it allows an alternative means to preserve the forage. The evaluation of smell, color and structure of silage are the best simple methods for determining the physical quality of silage during the ensiling process. This evaluation system has been commonly used for years in silage because it is an inexpensive and quick method (42). Open green colour, aromatic scent, such as bouquet and good structure, are desired in a high-quality silage (23). In the present study, smell, colour, structure score of alfalfa silage were significantly improved throughout the ensiling period. In alfalfa silages exposed to the fermantation weekly, quality class were determined as "mid" in the first week, as "good" among $2^{\text {th }}$ and $6^{\text {th }}$ weeks and "very good" at the end of study ( $7^{\text {th }}$ week), respectively. The improved quality of the alfalfa silage was attributed to increased power of fermentation during the weeks. Fermentation quality depends on certain factors such as inoculant type, LAB characteristics (36), environmental temperature nutritive value and type of silage (38)

The Flieg point, determined based on the $\mathrm{pH}$ value and DM of the silages, give an information about the its quality (14). In the present study, Flieg point was increased throughout the ensiling period. The improved Flieg point of the alfalfa silage was attributed to low $\mathrm{pH}$ and high DM. The high Flieg point is a sign of good preserved silages enhanced fermentation (13). The $\mathrm{pH}$ value of alfalfa silage used in Flieg point system is an important criterion to determine forage quality. There were a lot of studies to strong positive relationship between $\mathrm{pH}$ value and Flieg point (16).

As showed in Table 1, the $\mathrm{pH}$ value of alfalfa silage was linearly decreased throughout the ensiling period. The $\mathrm{pH}$ value was 6.09 at $\mathrm{d} 7$ of ensiling and dropped down to 5.15 at $\mathrm{d} 49$ of ensiling. There was significant increase in $\mathrm{NH}_{3}-\mathrm{N} / \mathrm{TN}$ content of alfalfa silage during the weeks its $\mathrm{NH}_{3}-\mathrm{N} / \mathrm{TN}$ content of alfalfa silage were $9.66 \%$ at $\mathrm{d} 7$ of ensiling days and $15.70 \%$ at d 49 of ensiling days. Wang et al. (35) reported that increase level of non-Protein-N due to gradually degradation of plant proteins affects silage fermentation. Because, ammonia, amines and amino acids prevent to the desired rapid decline in silage $\mathrm{pH}$ (33). Park and Stronge (27) reported that silages treated with $\mathrm{LAB}$ were low $\mathrm{pH}$ and high lactic acid concentration resulted in low degradation of protein. The sufficiently low $\mathrm{pH}$ value in silage is desirable, which could inhibit the spoilage microorganism, resulting in lower DM loss in LAB silage (30). The competing microorganism die due to the quickly increased LAB count at the initial fermentation (36). According to the Wilkinson (37) indicated that NH3-N/TN content of alfalfa silage should be fewer than $50 \mathrm{~g} / \mathrm{kg}$ of in ensiled silage. Addition of LAB in silage significantly limited proteolysis caused to enhance the protein utilization. It is indicated that NH3-N/TN content in silages was increased because of the high-level degradation of protein fraction to ammonia (3). Dordevic et al. (12) stated that the lower NH3-N/TN content was achieved in LAB treated silage and it might be due to lower $\mathrm{pH}$ and higher lactate content. Zhang et al. (41) showed that the ammonia combines with $\mathrm{H}^{+}$to form $\mathrm{NH}_{4}^{+}$which limits the $\mathrm{pH}$ of silage from reaching the required $\mathrm{pH}$ level. The same author stated that protease activity highly in alfalfa dependent on $\mathrm{pH}$ level and temperature.

Acetate and lactate concentration were increased, while propioante and butyrate concentration were decresed throughout the ensiling period. Dordevic et al. (12) reported that silage with LAB increased acetate concentration compared to control. The higher acetate production might be limiting the growth of yeast and moulds (39). Lactate concentration was dramatically increased by 12 -fold on 35-d as compared to $28 \mathrm{~d}$. Zhao et al. (42) found that lactic acid concentration peak at $d 30$ of ensiling. LAB, especially Lactobacillus plantarum, could enhanced the fermentation resulting in the decline of $\mathrm{pH}$ (38). Filya et al. (13) reported that addition of LAB significantly increased the lactobacilli count, whereas decreased yeast, mold clostridia and enterobacteria count after $2 \mathrm{~d}$ of ensiling due to the higher acidification of silage thereby improving the fermentation of silage. Butyrate and propionate concentrations were very low level in silage at $\mathrm{d} 49$ of ensiling. This is consistent with the results of Wang et al. (36) who revealed that propionic acid and butyric acid were not detected in silage. This could be attributed by the addition $\mathrm{LAB}$ reduce the $\mathrm{pH}$ which may have limited the growth of proteolytic microorganism such as Clostridia spp.

As shown in Table 2, ensiling period has a significant effect on DM, CP, CF, NDF, and ADF. DM in silage was linearly increased throughout the ensiling period, which was $33.43 \%$ at $\mathrm{d} 49$ of ensiling. Factors such as DM, WSC, $\mathrm{CP}$ of alfalfa silage and air exposure affects the preservation and fermentation of silage (27). DM of silage is a good indicator of the degree of fermentation (25). Some silage additives such as LAB and organic acids could increase the DM intake due to their growthenhancing for desirable bacteria (30) and antimicrobial properties (40) against undesirable bacteria. In the present study, CP was increased during the weeks. This could be partially explaining the increases proteolysis resulted in higher $\mathrm{NH}_{3}-\mathrm{N} / \mathrm{TN}$ content of alfalfa silage (17). Reductions in the concentration of CP could be due to its degradation, which increases the production of ammonia nitrogen (31) In the present study, the alfalfa silage had a $\mathrm{CF}$ of $25.83 \%$, and the contents of NDF and ADF were 
$36.70 \%$ and $29.68 \%$, respectively on d 49 of ensiling. Results obtained in this study are in agreement with those of Yan et al. (38) who stated that the fibrinolytic enzymes produced by LAB could degrade NDF and ADF. Rajabi et al (28) indicated that a low NDF and ADF level treated with LAB is probably because of higher hydrolysing of plant cell wall content in silo (28). The cell-wall contents (ADF, NDF) are important quality parameters of alflafa silage, which affect the digestibility of silage and animal performance. LAB degrade the cellular walls of alfalfa silage during the fermentatiton (12).

To establish a base-point to better determine where RFV's rate on the quality scale, it can be noted that an $\mathrm{ADF}$ of $41 \%$ and an NDF of $53 \%$ would relate to an RFV of 100 points. When the RFV value increased above 100 points quality of forage was higher; but, RFV decreased below 100 it was lower (32). In this study, obviously, there were significant effects of different ensiling days on DDM, DMI and RFV $(\mathrm{P}<0.05)$. These findings are in line with those of Turan and Önenç (32) who expressed that RFV was positively improved by addition silage additive. Canbolat et al. (5), reported that addition of grape pomace significantly increased the RFV and DMI due to decrased NDF and ADF content of alfalfa silage. Higher RFV and TDN are indication of good fermentation quality of the alfalfa silage (12). The high level of NDF and ADF in silage are hereby known to induce a feeling of satiety (appetite suppression), reduced the digestion, which limit the feed intake (34).

As a conclusion, smell, color and structure of silage improved after $\mathrm{d} 28$ of ensiling. The $\mathrm{pH}$ value was significantly decreased and Flieg point was increased at the $\mathrm{d} 28$ of ensiling. There were significant differences in the CF, NDF and ADF after d 21 of ensiling. Acetate concentration was increased but propionate and butyrate concentration were decreased throughout the ensilig period. Lactate concentration was dramatically increased by 18 -fold on $\mathrm{d} 35$ as compared to $\mathrm{d} 28$. Consequently, the present study stated that the fermentation of alfalfa silage could be improved after d 28 of ensiling. Once silage is packed, some manufacturer offers the silage that is very poor-quality for animal nutrition. Considering the results of this study, it could be suggested that the alfalfa silage should be offered no sooner than 4 weeks for animal to provide high quality nutritive value of alfalfa silage. However, more researches with alfalfa silage are required to be conducted to determine the effects of different ensiling days on fermentation quality in the field conditions.

\section{Acknowledgements}

This research article was summarized from the first author's master thesis.

\section{Financial Support}

This study was supported by MAKUBAP (0548-YL$18)$

\section{Ethical Statement}

This study does not present any ethical concerns.

\section{Conflict of Interest}

The authors declared that there is no conflict of interest.

\section{References}

1. Adesogan AT (2009): Challenges of tropical silage production. 139-154. In: Proocedings of $15^{\text {th }}$ International Silage Conference. Universtiy of Wisconsin, Madison.

2. AOAC (1990): Association of Official Analytical Chemists. 69-88. In: K Helrich (Ed), Official Methods of Analysis. USA.

3. Borreani G, Tabacco E, Schmidt RJ, et al (2018): Factors affecting dry matter and quality losses in silages. J Dairy Sci, 101, 3952-3979.

4. Broderick GA, Kang JH (1980): Automated simultaneous determination ofammonia and total amino acids in ruminal fluid and in vitro media. J Dairy Sci, 63, 64-75.

5. Canbolat Ö, Kalkan H, Karaman Ş, et al (2010): The investigation of possibility of grape pomace as carbohydrate source in alfalfa silages. Kafkas Univ Vet Fak Derg, 16, 269-276.

6. Chiba S, Chiba H, Yagi MA (2005): A Guide for Silage Making and Utilization in the Tropical Regions. 29. In: A publication of the Japanese Livestock Technology Association, Tokyo: Ministry of Agriculture, Foresty and Fisheries, Japan.

7. Crampton EW, Maynard LA (1938): The relation of cellulose and lignin content to nutritive value of animal feeds. J Nutr, 15, 383-395.

8. Dawson B, Trapp RG (2001): Basic and Clinical Biostatistics. Lange Medical Books/ McGraw-Hill Medical Publishing Division, New York, USA.

9. DLG (1997): DLG-Schlussel zur Beurteilung der Garqualita $t$ von Grunfuttersilagen auf der Basis der chemischen Untersuchung. [DLG-pattern for the Evaluation of the Fermentation Quality of Grass Silages on the basis of Chemical Analyses]. Frankfurta. M.: Deutsche Landwirtschafts-Gesellschaft.

10. Dong Z, Yuan X, Wen A, et al (2017): Effects of calcium propionateon the fermentation quality and aerobic stability of alfalfa silage. Asian-Australas J Anim Sci, 30, 12781284.

11. Doonan BM, Kaiser AG, Stanley DF, et al (2004): Silage in the Farming System. 1-24. In: AG Kaiser, JW Piltz, HM Burns, NW Griffiths (Eds), Successful Silage, Chapter 1. New South Wales Dept. Of Primary Indusrtry, Orange.

12. Đorđević S, Mandić V, Stanojević D (2016): The effect of bacterial inoculant on chemical composition and fermentation of alfalfa silage. Biotech Anim Hus, 32, 413423.

13. Filya I, Ashbell G, Hen Y, et al (2000): The effect of bacterial inoculants on the fermentation and aerobic 
stability of whole crop wheat silage. Anim Feed Sci Technol, 88, 39-46.

14. Gallo A, Giuberti G, Bruschi S, et al (2015): Use of principal factor analysis to generate a corn silage fermentative quality index to rank well-or poorly-preserved forages: Corn silage fermentative quality index definition. $\mathrm{J}$ Sci Food Agric, 96, 1686-1696.

15. Goering HK, Van Soest PJ (1970). Forage Fibre Analysis, Agric Handbook. Department Agriculture. Washington, DC, USA.

16. Karakozak E, Ayaşan T (2010): Effect of inoculant in silages in which diffirent forage crops and their mixtures on Flieg point and crude nutrient content. Kafkas Univ Vet Fak Derg, 16, 987-994.

17. Kim JG, Ham JS, Li Y, et al (2017): Development of a new lactic acid bacterial inoculant for fresh rice straw silage. Asian-Australasian J Anim Sci, 30, 950-956.

18. Kleinschmit DH, Kung LA (2006): A meta-analysis of the effects of Lactobacillus buchneri on the fermentation and aerobic stability of corn and grass and small-grain silages. J Dairy Sci, 89, 4005-4013.

19. Kung L, Stokes MR, Lin CJ (2003): Silage Additives. 305-360. In: Silage, science and technology. Agronomy Monograph, Wisconsin, USA.

20. Liu C, Lai YJ, Lu X, et al (2016): Effect of lactic acid bacteria inoculants on alfalfa (Medicago sativa L.) silage quality: Assessment of degradation (in situ) and gas production (in vitro). J Integr Agric, 15, 2834-2841.

21. Liu QH, Dong ZH, Shao T (2018): Effect of additives on fatty acid profile of high moisture alfalfa silage during ensiling and after exposure to air. Anim Feed Sci Technol, 236, 29-38.

22. Meeske R (2005): Silage additives: Do they make a difference? S Afr J Anim Sci, 6, 49-55.

23. Muck RE, Nadeau EMG, McAllister TA, et al (2018): Recent advances and future uses of silage additives. J Dairy Sci, 101, 3980-4000.

24. Ni K, Wang F, Zhu B, et al (2017): Effects oflactic acid bacteria and molasses additives on the microbial community andfermentation quality of soybean silage. Bioresour Technol, 238, 706-715.

25. Oladosu Y, Rafii MY, Abdullah N, et al (2016): Fermentation quality and additives: A case of rice straw silage. Biomed Res-Int, 13, 1-14.

26. Pahlow G, Muck RE, Driehuis F, et al (2003): Microbiology of Ensiling. 31-94. In: Buxton DR, Muck RE, Harrison JH (Eds), Silage Science and Technology, American Society of Argonomy, Washington, D.C.

27. Park RS, Stronge MD (2013): Silage Production and Utilisation. 98-99. In Proceedings of $14^{\text {th }}$ Proceedings of the International Silage Conference, Wageningen Academic, The Netherlands.

28. Rajabi R, Tahmasbi R, Dayani O, et al (2016): Chemical composition of alfalfa silage with waste date and its feeding effect on ruminal fermentation characteristics and microbial protein synthesis in sheep. J Anim Physiol An N, 101, 466-474.
29. Redfearn D, Zhang H (2014): Forage Quality Interpretations. Oklahoma Cooperative Extension Service, PSS-2117. Available at http://factsheets.okstate.edu/ (Accessed March 2, 2019).

30. Silva VP, Pereira OG, Leandro ES, et al (2016): Effects of lactic acid bacteria with bacteriocinogenic potential onthe fermentation profile and chemical composition of alfalfa silage in tropicalconditions. J Dairy Sci, 99, 18951902.

31. Suzuki M, Lund CW (1980): Improved gas-liquid chromatography for simultaneous determination of volatile fatty acids and lactic acid in silage. J Agric Food Chem, 28, 1040-1041.

32. Turan A, Önenç SS (2018): Effect of cumin essential oil usage on fermentation quality, aerobic stability and in vitro digetibility of alfalfa silage. Asian-Australas J Anim Sci, 31, 1252-1258.

33. Uher D, Konjačić M, Jares D, et al (2019): The effect of bacterial inoculant on chemical composition and fermentation of alfalfa silage. J Cent Agr, 20, 657-64.

34. Van Soest PJ (1994): Nutritional Ecology of the Ruminant. Cornell University Press, Ithaca, NY.

35. Wang J, Wang JQ, Zhou H, et al (2015): Effects of addition of previously fermented juice prepared from alfalfa on fermentation quality and protein degradation of alfalfa silage. Anim Feed Sci Technol, 151, 280-290.

36. Wang S, Yuan X, Dong Z, et al (2017): Characteristics of isolated lactic acid bacteria and their effects on the silage quality. Bioresour Technol, 30, 819-827.

37. Wilkonson JM (1999): Silage and animal health. Natural Toxins, 7, 212-230.

38. Yan Y, Li X, Guan H, et al (2019): Microbial community and fermentation characteristic of Italian ryegrass silage prepared with corn stover and lactic acid bacteria. Bioresour Technol, 279, 166-173.

39. Yang L, Yuan X, Li J, et al (2018): Dynamics of microbial community and fermentation quality during ensiling of sterile and nonsterile alfalfa with or without Lactobacillus plantarum inoculant. Bioresour Technol, 275, 280-287.

40. Yuan X, Wen A, Desta ST, et al (2017): Effects of four short-chain fatty acids or salts on the dynamics of nitrogen transformations and intrinsic protease activity of alfalfa silage. J Sci Food Agric, 97, 2759-2766.

41. Zhang Q, Zhao M, Wang X, et al (2017): Ensiling alfalfa with whole crop corn improves the silage quality and in vitro digestibility of the silage mixtures. Jpn Soc Grassland Sci, 63, 211-217.

42. Zhao J, Dong Z, Li, J, et al (2019): Effects of lactic acid bacteria and molasses on fermentation dynamics, structural and nonstructural carbohydrate composition and in vitro ruminal fermentation of rice straw silage. Asian-Australas J Anim Sci, 32, 783-791.

43. Zielińska K, Fabiszewska A, Stefańska I (2015): Diffirent aspects of Lactobacillus inoculants on the improvement of quality and safety of alfalfa silage. Chil J Agr Res, 75, 298306. 